\title{
A ESCOLA COMO ATRAÇÃO URBANA: AS ENCENAÇ̃̃ES DE ESPETÁCULOS EDUCACIONAIS NO RIO DE JANEIRO E EM BUENOS AIRES NOS ANOS 1920
}

José Cláudio Sooma Silva*

RESUMO: $\mathrm{O}$ artigo dialoga com as pesquisas que têm procurado perscrutar a circulação de modelos e práticas de escolarização entre o Brasil e a Argentina. Este conjunto de reflexões vem se esforçando para aclarar os cuidados que devem acompanhar os interesses investigativos daqueles que se dispõem a aceitar o desafio de construir um exercício comparativo. Dentre estes cuidados, talvez o maior seja aquele referente à preocupação em realçar não apenas as proximidades, mas fundamentalmente, as singularidades históricas das circunstâncias analisadas. Alicerçado nessa perspectiva teórico-metodológica, foram problematizados aproximações e distanciamentos entre as encenações dos espetáculos educacionais protagonizadas pelas crianças no decurso dos anos 1920 no Rio de Janeiro e em Buenos Aires. Nesse sentido, estiveram em atenção as motivações que concorreram para que, tanto naquela cidade quanto nesta, tais ocasiões fossem empregadas para a disseminação de preceitos educativos pelos ambientes urbanos.

Palavras-chave: História da Educação; Espetáculos Educacionais; História Comparada.

THE SCHOOL AS AN URBAN ATTRACTION

THE STAGING OF EDUCATIONAL SPECTACLES IN RIO DE JANEIRO AND BUENOS AIRES IN THE 1920'S

ABSTRACT: This article dialogues with the researches that have been trying to peer the circulation and practices of schooling in Brazil and Argentina. This group of reflections has been striving to clarify the necessary care that must follow the investigative interests of the ones who are willing to accept the challenge of building a comparative exercise. Among theses cares, the biggest one may be the one regarding the preoccupation in highlighting, not only the proximities, but, fundamentally, the historical singularities of the analyzed circumstances. Anchored in this theoretical-methodological perspective, approximations and detachments between the staging of educational spectacles featured by children along the 1920's in Rio de Janeiro and Buenos Aires were questioned. In that sense, the motivations that played a role in both cities were in the focus so that such occasions were employed for the dissemination of educational precepts by urban environments.

Keywords: Education History; Educational Spectacles; Compared History.

* Doutor em Educação pela Universidade do Estado do Rio de Janeiro (UERJ) e Professor Adjunto da Universidade Federal do Rio de Janeiro (UFRJ). E-mail: claudiosooma@gmail.com 


\section{As encenações cariocas}

A década de 1920, momento de consolidação da vida urbana na cidade do Rio de Janeiro (OLIVEIRA, 1991; HERSCHMANN \& PEREIRA, 1994; MONARCHA, 1989, BRETAS, 1997, ARAÚJO, 1993), foi marcada por um entrelaçamento da ciência do urbanismo com os saberes e práticas proporcionados pela educação primária. Sob a lógica governamental, escola e cidade passaram a ser concebidas de modo articulado, tendo em vista um repertório comum de estratégias, porque se ansiava converter a cidade em um espaço educativo e a escola, em um dispositivo para incutir ideais de comportamento e de higiene pública.

Esse movimento procurou inventar uma tradição de urbanidade na antiga capital. Algo que, relacionado aos problemas de circulação e de ocupação preponderantes no período, passou pelo esforço de (re)significar as iniciativas de reforma do espaço público encampadas pelas administrações municipais a partir da virada do século XIX para o XX1. Como, também, pelo anseio de multiplicar na população condutas projetadas como adequadas para a harmonização e o disciplinamento do cotidiano.

Tais preocupações confluíram para que a educação primária fosse pensada como uma modalidade de intervenção social que poderia explicar as transformações ocorridas, ensinando diferentes modos de viver a cidade. Afinal, o contato diário e frequente contribuiria para que a comunidade escolar incorporasse e divulgasse certo número de preceitos educativos que produziria modificações benéficas no meio social.

Por preceitos educativos compreendia-se um conjunto de saberes e práticas trabalhado no ensino primário que, de algum modo, produziria interferências nos pensamentos, condutas e hábitos. Dessa forma, para que fosse viável a disseminação entre os cariocas, era necessário que se encontrassem incorporados na mente, no corpo, nos gestos da comunidade escolar, de tal maneira que o próprio modo de agir, falar e se comportar dessas crianças e desses adultos os distinguissem dos demais integrantes da sociedade.

Nesse quadro, de início, era preciso nos espaços e tempos intramuros escolares disciplinar as circunstâncias que, porventura, destoassem dos preceitos educativos enfatizados. Por conta de a cidade ter invadido as escolas no período (NUNES, 1994, p. 201), tratava-se, no fundo, de uma tentativa de controlar os convites à dispersão que se encontravam, farta- 
mente, presentes ao cotidiano, por exemplo: impropérios dirigidos aos/às alunos/as e professores/as por adultos e crianças nas grades e portões dos estabelecimentos de ensino; jogatinas realizadas nas proximidades das escolas; sujeitos armados às portas das instituições educativas; algazarras efetivadas dentro e/ou nas localidades circunvizinhas aos prédios escolares; existência de animais nos arredores dos edifícios (SILVA, 2009, p. 123 e ss.).

No entanto, de nada ou muito pouco adiantariam esses esforços empreendidos nos espaços e tempos intramuros se o investimento não recaísse também em uma tentativa de fazer com que a comunidade escolar internalizasse a certeza desse estado de observação e fiscalização constantes e, de algum modo, produzisse interferências nos comportamentos dos demais habitantes. Colocado de outra forma, no caso das crianças, como apenas durante um período do dia e uma fase de sua existência estariam sob a influência direta dos preceitos educativos primários ${ }^{2}$, a expectativa era de que continuassem a refleti-los no decurso de sua vida. Já no caso dos adultos, embora se possa aventar a possibilidade de trabalharem em dois ou mais períodos do dia e, também, pontuar um tempo maior de contato ao longo de seus anos de atuação profissional, ainda assim a aposta incidia sobre a importância de incorporarem os aludidos preceitos educativos em seu cotidiano de modo que se tornassem exemplos edificantes.

Sublinhar esse estado de observação e fiscalização constantes que, estrategicamente, deveria ser internalizado e propagado pelo meio social carioca significa atentar para a impregnação das escolas sobre a cidade (NUNES, 1994, p. 201) que concorreu para que "[...] múltiplos eventos, dentro e fora da escola (nas ruas, nas praças e nos teatros), ganha[ssem] vigor de uma dramaturgia" (NUNES, 2000, p. 391); dentre estes acontecimentos - os espetáculos educacionais - destacaram-se: saudação à visita do Rei Alberto e da Rainha Elisabeth da Bélgica, organizada na Quinta da Boa Vista; solenidade para o centenário do "Dia do Fico"; cerimônia de trasladação dos restos mortais de Estácio de Sá e de relíquias da cidade do Rio de Janeiro; "Festa da Bandeira"; frequência a teatros e circos, excursão ao Museu Nacional, visita a cemitério, expedição a matadouro, realização de exercícios ginásticos e jogos diversos em praças e praias, passeio à Quinta da Boa Vista.

A importância adquirida por esses espetáculos educacionais e a frequência com a qual eram encenados no ambiente urbano da capital no 
decurso dos anos $1920^{3}$ não foram casuais. O investimento incidia sobre as possíveis influências que a organização, a harmonia, a disciplina, o controle estampados nos comportamentos, gestos e corpos dos escolares poderiam ocasionar no meio social. Ansiava-se, assim, que o efeito cênico dessas atrações urbanas continuasse a ser rememorado, mesmo após o término das apresentações. Por outras palavras, que os habitantes retornassem às suas comunidades refletindo sobre o que observaram e, de preferência, que modificassem suas próprias condutas.

Nesse quadro, as comemorações, solenidades, prática de exercícios ginásticos e outros acontecimentos urbanos que contavam com a presença de escolares adquiriam formas, mesmo, de um "teatro da modernidade". Um espetáculo que, sob a lógica de disciplinar e organizar o cotidiano, ansiava ensinar os escolares e a população a "praticar a cidade, [a] transitar por ela, [a] vivenciá-la corporalmente [e simbolicamente], isto é, provar a cidade com o corpo, isso era já uma forma [...] de fazer o corpo se impregnar da racionalidade, da higiene, da assepsia, da civilidade desejada [...]" (VAGO, 2002, p. 34).

Praticar a cidade e transitar por ela. Atentar para essas duas concepções que estavam também incluídas nos ideais que motivavam a concretização dos eventos com a participação dos escolares pelo ambiente urbano significa iluminar outra dimensão desses espetáculos educacionais: alguns fatores relacionados aos, para manter o movimento metafórico, momentos bastidores. Ou seja, aquilo que tinha de ser mobilizado antecipadamente para que essas encenações pudessem acontecer.

Ressaltar a importância adquirida pelos momentos bastidores como circunstâncias contribuintes à difusão de ideais de harmonia e disciplina significa considerar um aspecto fundamental nessa relação estabelecida entre a comunidade escolar e o ambiente urbano carioca: os necessários deslocamentos dos escolares pela cidade para chegarem até aos locais dos eventos (escolas, praças, campos de futebol, ruas, avenidas, praias, etc.), algo, portanto, que remete às práticas da cidade e aos trânsitos por ela. Em várias ocasiões, como se pode acompanhar a seguir, a Diretoria de Instrução se encarregava de fornecer os carros motores e reboques para o transporte dos alunos: 
[1] Sr. Diretor Geral de Obras e Viação

Solicito vossas providências para que, no dia 14 do corrente às 14 horas, esteja na Praça Duque de Caxias, um carro motor dos grandes com um reboque, afim de conduzirem os alunos da escola José de Alencar para o Teatro Municipal. (O Diretor Geral, 11 de julho de 1922).

[2] Sr. Diretor Geral de Obras e Viação

Peço-vos providencieis para que sejam postos à disposição da escola da rua Barão do Bom Retiro no. 234, um carro motor e um reboque para transportarem 200 alunos da referida escola para a Quinta da Boa Vista (ida e volta), no dia 23 do corrente, às 9 e meia da manhã [...]. (O Diretor Geral, 16 de setembro de 1925$)^{5}$.

Por essas solicitações, e outras muitas que se encontram presentes no Arquivo Geral da Cidade do Rio de Janeiro ${ }^{6}$, podem-se indiciar outras situações que reforçam a concepção de que as circunstâncias escolares invadiam a cidade. Aqui se estão considerando os possíveis comentários gerados em razão das interferências desses meios de transporte no ambiente urbano carioca. Afinal, uma das características marcantes do período era o problema de tráfego, que fazia com que congestionamentos, colisões, acidentes, atropelamentos, etc. se multiplicassem (SILVA, 2009). Nesse sentido, estariam esses bondes carregados de alunos, também, em meio às disputas por espaços nas ruas e avenidas destinadas à sua circulação.

Mas não só isso. Em termos estratégicos, a circulação desses carros motores poderia despertar a curiosidade da população acerca do que acontecia nos eventos escolares, instigando a sua participação. Nesse sentido, parece pertinente atribuir ao trânsito desses bondes carregados de alunos uma conotação de estimulador de mais e novas conversas referentes aos assuntos sobre a educação nos espaços e tempos citadinos. Isso, é bom que se reafirme, antes mesmo de os espetáculos educacionais ocorrerem.

Todavia, os bondes se constituíam como uma das dimensões envolvidas no fortalecimento e na divulgação dos assuntos sobre a educação na capital a partir dos deslocamentos dos escolares. No que tange, ainda, aos momentos bastidores dos espetáculos educacionais, tão significativas quanto o trânsito desses veículos, senão mais, foram aquelas circunstâncias nas quais o transporte dos alunos não esteve sob a responsabilidade da Diretoria de Instrução. 
Cumpre aclarar que essa situação foi, inclusive, enaltecida por Carneiro Leão, no relatório que elaborou ao encerrar suas atividades à frente da Diretoria Geral de Instrução Pública (1922-1926). Em alusão aos momentos de ensaio e à apresentação do "formosíssimo espetáculo" (CARNEIRO LEÃO, 1926, p. 95) que, em 1924, reuniu 2 mil crianças no campo do Botafogo Futebol Clube, ele se manifestou do seguinte modo:

Convém salientar que, para realização desta prova, não pouparam esforços nem despesas de transporte nem instrutores, nem professores, nem alunos. Por várias vezes inúmeras escolas se transportaram, à sua própria custa, aos Campos de Futebol e em duas manhãs se realizaram ensaios gerais com cerca de duas mil crianças, sem que à Prefeitura fosse pedido auxílio pecuniário algum (CARNEIRO LEÃO, 1926, p. 102).

As palavras de Carneiro Leão devem ser entrelaçadas à questão de que, a rigor, nenhuma solicitação de transporte para alunos foi encaminhada pela Diretoria de Instrução para esse evento escolar de 1924 e para os outros dois dessas proporções que ocorreram em 1925 e $1927^{7}$. Nessa linha, parece pertinente a ponderação de que, a fim de chegarem até à localidade, diversos habitantes tiveram de realizar deslocamentos pelos espaços e tempos citadinos. Se essa afirmação parece plausível, não menos coerente é a de que tal situação produziu interferências em diversos aspectos do ambiente urbano, incluindo disputas por lugares e assentos nos trens, bondes e auto-ônibus, além de adensamento da circulação de pedestres, circunstâncias que emergiram pelo grande trânsito de habitantes trilhando, simultaneamente, a mesma direção.
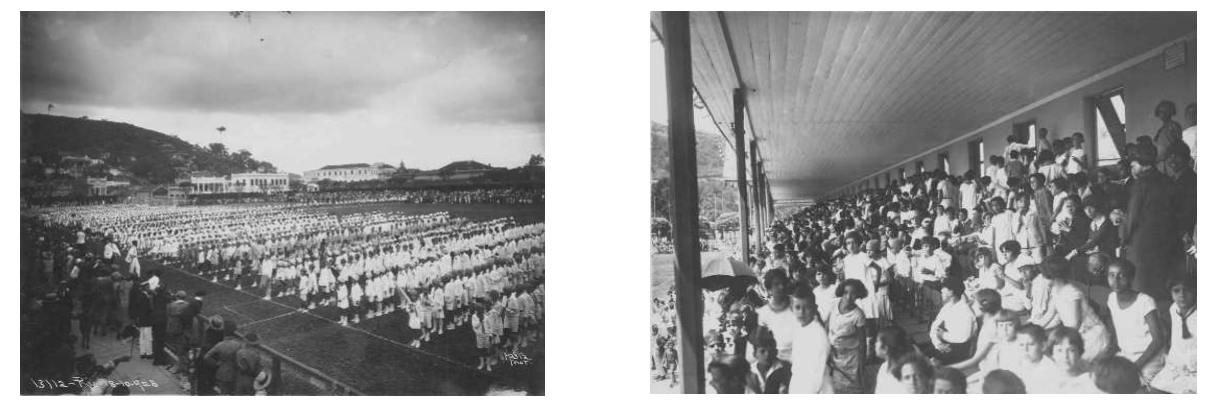

Fotos 1 e 2. Evento com 4 mil escolares (18/10/1925)

Fotógrafo: Augusto Malta

Fonte: Museu da Imagem e do Som (RJ) / Coleção Augusto Malta 
Se assim foi, projetar luzes para esse trânsito significa, também, sublinhar a possibilidade de novas modalidades de repercussão, muitas delas por vias indiretas, dos preceitos educativos na capital. Nesse ponto, a alusão passa pelos comportamentos, vestimentas, falas dos escolares, que poderiam ser percebidos pela população carioca por conta dessas relações cotidianas estabelecidas ao longo do percurso rumo ao "palco" do espetáculo educacional. Desta feita, tais situações de visualização da comunidade escolar e interação com a mesma em diferentes circunstâncias urbanas sugerem que esses deslocamentos concorreriam, estrategicamente, para a intensificação das temáticas relacionadas à educação no meio social.

À vista dessas considerações, pode-se afirmar que pensar esses momentos bastidores contribui para perspectivar os espetáculos educacionais por outros olhares que não exclusivamente aqueles voltados para as encenações. Isso, acredito, constitui uma chave de entrada importante para analisar os possíveis significados que essas experiências educativas adquiriram no ambiente urbano carioca dos anos 1920.

\section{As encenações portenhas}

$\mathrm{Na}$ cidade de Buenos Aires, principalmente a partir de finais do século XIX, as necessidades e exigências sociais de pôr fim a "la realidad urbana caótica" confluíram para que as medidas de governo da população voltassem suas atenções para o entrelaçamento de "los temas urbanos e territoriales" com aqueles relacionados à ordem da "higiene urbana" (LIERNUR; SILVESTRI, 1993, p. 141, 153). Fortalecia-se, assim, a concepção de que as iniciativas de intervenção no espaço público deveriam se esforçar para "definir las políticas urbanas, en los términos higiénicos que trasuntaba la mirada moderna sobre la ciudad” (LIERNUR; SILVESTRI, 1993, p. 153).

Quer isso dizer que a partir desse momento, de modo cada vez mais intenso, passou a ocorrer um entrelaçamento das instâncias médicohigiênicas com as políticas de remodelação urbana. Conforme os ditames da higiene, o desafio era operar um deslocamento nas preocupações de salubridade pública: da cura para a prevenção (Cf. GONDRA, 2004). Esperava-se, por esse veio, que as características arquitetônicas facultassem as condições para as doenças serem prevenidas. 
Esse quadro contribuiu para que, entre outras modalidades de intervenção social, as preocupações governamentais fossem direcionadas para a educação primária. Intensificava-se a concepção de que para a modernização de Buenos Aires, afora os empreendimentos de reconfiguração do traçado arquitetônico, apresentava-se como imprescindível educar os comportamentos e hábitos da população de modo que os habitantes empreendessem condutas modernas em seu cotidiano (LIONETTI, 2007, p. 31).

Com efeito, reorganizar a cidade e educar a população configuraram-se como investimentos complementares dentro das coordenadas traçadas pelas duas estratégias de intervenção pública que alicerçaram o planejamento urbano no período: "la grilla y el parque" (GORELIK, 2004). A primeira correspondeu ao esforço de promover um quadriculamento que, pautado no predomínio da superfície plana, se encarregou de planejar a reconfiguração dos espaços citadinos como se estivesse fundando "una ciudad sobre la nada" (GORELIK, 2004, p. 34). Desta feita, avenidas, ruas, bairros, edificações, etc. foram pensados, em termos estratégicos, em função dos auxílios que prestariam para o bom andamento do conjunto das obras. No tocante aos parques e praças públicas, as iniciativas governamentais da capital portenha voltaram-se para tais equipamentos urbanos, concebendo-os como "manuales de instrucciones para el uso de la metrópoli [...] para producir la transformación radical de "estado de cultura" de las nuevas multitudes urbanas". Estrategicamente, funcionariam "como regeneradores higiénicos y cívicos, como aglutinadores morales”. Daí eles estarem “en todas las partes” (GORELIK, 2004, p. 165).

À vista dessas considerações, no que tange à produção do conhecimento em História da Educação argentina, segundo Lucia Lionetti, constata-se uma concordância na "mayoría de los trabajos que se han ocupado de analizar el sistema educativo" de que esse fortalecimento da educação como uma intervenção social foi impulsionado pelos ideais de disciplinar, higienizar e incutir preceitos de nacionalidade entre os habitantes, integrando-os "bajo el colectivo de ciudadanos" (2005, p. 1.226) Acerca desse aspecto específico, outra concordância tem se desenhado na comunidade de historiadores argentinos. Sob diversificados enfoques, as atenções dos pesquisadores se voltaram para a Ley de Educación Común (1420), que, sancionada em 1884, durante a presidência de Julio A. Roca, regulamentou o ensino primário da Capital Federal e demais Territórios 
Nacionais. Pelas palavras de Oscar Oszlak, “o debate em torno da Ley 1420 de educação comum [...] vinculou-se estreitamente com o papel da educação primária como instrumento de controle social" (apud SOARES, 2007, p. 32).

Ao assinalar esse vínculo da educação primária com as estratégias de controle social, dois fatores devem ser considerados. O primeiro se refere aos impactos da Revolução Científico-Tecnológica de 1870, que, pautada nos derivados energéticos resultantes da eletricidade e do petróleo, ocasionou alterações substanciais, sem exagero, em todos os aspectos do cotidiano das cidades. No bojo desse curso de mudanças profundas, foram instituídos outros referenciais de tempo e de espaço nas populações, modificando "seus modos de perceber os objetos ao seu redor, de reagir aos estímulos luminosos, a maneira de organizar suas afeições e de sentir a proximidade ou o alheamento de outros seres humanos" (SEVCENKO, 1998, p. 7). A rigor, a iluminação pública, a eletrificação do transporte coletivo e a entrada no cenário dos veículos automotores impulsionados pelo motor a combustão convergiram para uma inequívoca torção no cotidiano da cidade portenha a partir, principalmente, da década de 1880 (LIERNUR; SILVESTRI, 1993). Muitas das certezas que balizavam as interações citadinas foram revolvidas, fazendo com que os habitantes perdessem os referenciais de tempo, a noção de espaço e, mesmo, passassem a conviver com outras modalidades de perigos urbanos.

O segundo fator condiz à explosão populacional que marcou a Argentina como um todo e a cidade de Buenos Aires em particular entre finais do século XIX e primeiras décadas do XX. Esse fenômeno deveuse, principalmente, ao fluxo intenso de imigrantes europeus, como se pode acompanhar pelos quadros seguintes.

\section{Quadro 1. População total e porcentagem de estrangeiros na Argentina}

\begin{tabular}{c|c|c|c} 
Ano & $\mathbf{1 8 6 9}$ & $\mathbf{1 8 9 5}$ & $\mathbf{1 9 1 4}$ \\
\hline População Total & 1.700 .000 & 3.900 .000 & 7.800 .000 \\
\hline População de Estrangeiros & $205.700(12,1 \%)$ & $994.500(25,5 \%)$ & $2.363 .400(30,3 \%)$
\end{tabular}

Fonte: FAUSTO; DEVOTO, 2004, p. 174 
Quadro 2. População total e porcentagem de estrangeiros na cidade de Buenos Aires

\begin{tabular}{c|c|c|c} 
Ano & $\mathbf{1 8 8 7}$ & $\mathbf{1 8 9 5}$ & 1914 \\
\hline População Total & 432.661 & 663.854 & 1.560 .986 \\
\hline População de Estrangeiros & $128.167(30 \%)$ & $345.493(52 \%)$ & $766.156(49 \%)$
\end{tabular}

Fonte: FAUSTO; DEVOTO, 2004, p. 179

Como se infere, iluminar a participação dos imigrantes no crescimento populacional argentino significa entrar em contato com o país que, depois dos Estados Unidos, mais "atraiu imigrantes para as Américas” (FAUSTO; DEVOTO, 2004, p. 174)9. Tal ponderação adquire um significado mais importante se esses percentuais forem complementados com alguns números alusivos aos "trabalhadores sazonais (ou golondrinas)" que permaneceram por determinado tempo e retornaram à sua terra natal. Segundo Osvaldo Coggiola, de 1881 a 1890 aportaram 841 mil imigrantes, número que, na primeira década do século $\mathrm{XX}$, saltaria para 1.764.000; "no total, de 1857 a 1930, o deserto argentino recebeu 6.330.000 imigrantes” (COGGIOLA, 1997, p. 101) ${ }^{10}$.

Ainda no tocante aos quadros estatísticos, interessa sublinhar que, em valores aproximados, o número de habitantes do país quadruplicou entre 1869 e 1914; ao passo que o da capital portenha, entre 1887 e 1914, triplicou. Em termos do percentual de imigrantes, para o país, percebe-se aumento significativo de 1869 a 1895, tendência que permaneceu, embora em menor escala, de 1895 a 1914. Já para o caso da cidade de Buenos Aires, o que se nota é um aumento enfático do percentual de imigrantes no período de 1887 a 1895 e um pequeno decréscimo entre 1895 e 1914 (embora o índice permaneça bastante elevado, beirando os 50\%).

Em relação à capital portenha, a aceleração dos tempos sociais e o aumento considerável do número de habitantes fizeram com que as medidas de governo direcionassem suas atenções para aquelas preocupações que, de alguma forma, se encarregassem de "administrar as populações”. Isso significou que os planejamentos interessados em organizar o traçado das avenidas, ruas e calçamentos, disciplinar as interações cotidianas e harmonizar os equipamentos urbanos foram alçados à categoria de circunstâncias indispensáveis para o bom andamento do conjunto da sociedade (Cf. FOUCAULT, 2008, p. 142).

Em função desse quadro é que parecem pertinentes as ponderações de que foi a partir de finais do século XIX que se intensificou a con- 
cepção de pensar o cenário urbano a partir de suas possíveis influências didáticas para o aprendizado cotidiano, pela população, das formas modernas de praticar a cidade (Cf. GORELIK, 2004, p. 225). Dito de outro modo, sob a lógica governamental era necessário disseminar entre a multidão urbana preceitos de higiene, harmonia, abdicação de interesses pessoais em favor de aspirações coletivas.

Mas, ao lado dessas preocupações, para que a vida pública fosse viável, constituía-se como imprescindível a solidificação dos laços de identidade nacional. Esse anseio por "argentinizar" a população confluiu, também, para que a partir desse momento a educação primária fosse considerada "el mejor anticuerpo para preservar a la comunidad de la posible inestabilidad [...] ocasionada pela masa de extraños que no se consideraba parte de la nación" (LIONETTI, 2007, p. 46-47). Destarte, em concomitância à inculcação de concepções higiênicas, ideais de urbanidade, disciplinarização dos comportamentos, houve um investimento em se trabalhar os preceitos de uma "ensenãnza patriótica en un país de inmigración" (PUIGGRÓS, 1992 , p. 55). Afinal, era nos tempos e espaços escolares que se teria a oportunidade de, diariamente, converter as características do ambiente urbano em temas a serem explorados junto àquela parcela populacional que, irrevogavelmente, seria o futuro da cidadania argentina: as crianças. Nesse movimento para "el proyecto civilizador" que seria desempenhado pelo ensino primário, "los ejemplos de la vida cotidiana [y] la inmigración que afluía constantemente al país" foram incorporados ao conteúdo programático. Ao fim e ao cabo, almejava-se que os alunos apreendessem e, estrategicamente, difundissem entre seus familiares, vizinhos, conhecidos, enfim, na população, o "conjunto de los deberes y obligaciones que t[endría] que cumplir el ciudadano" (Cf. LIONET'TI, 2007, p. 247-248).

Dessa perspectiva, nada casual foi a iniciativa do Consejo Nacional de Educación, em 1890, de regulamentar as comemorações das datas pátrias. Por esse decreto, segundo as reflexões de Cecília Olarón:

[...] se estableció que los escolares y sus maestros se manifestarían en las plazas y paseos públicos de la ciudad, de modo tal que los batallones infantiles formados oficialmente en 1888 - iban a saludar a su madre patria muy temprano para despertar el sentimiento patriótico (2005, p. 82).

Com essa medida ficava instituída legalmente a estratégia de imprimir um movimento de "argentinización de la escuela", no qual os 
espetáculos educacionais passavam a desempenhar "un rol protagónico en la constitución de identidades socio-espaciales, en función de su capacidad simbólica y material de encarnar un conjunto de valores públicos, como cadena de transmisión e inclusión en ellos" (GORELIK, 2004, p. 299). Dentre esses valores públicos que seriam encarnados nessas encenações pelos espaços e tempos citadinos destacavam-se os alusivos a "la integración social y nacional” (GORELIK, 2004, p. 299).

A rigor, sob o ideal de propagar esses preceitos, a capital portenha foi convertida em palco para as encenações dos espetáculos educacionais. Nesses eventos, grande atenção era conferida à organização, à harmonia e ao disciplinamento dos "miles y miles de niños" (GVIRTZ; AUGUSTOWSKY, 2002, p. 65), de modo que comportamentos adequados, cuidados com o asseio, ideais de respeito aos símbolos pátrios pudessem ser visualizados.

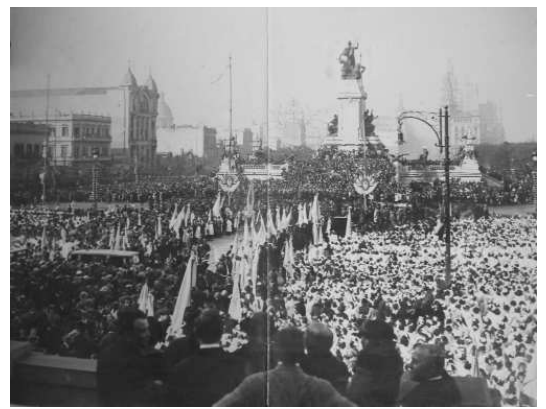

Foto 3. Desfile escolar (s.d.) / Fonte: Archivo General de La Nación (Buenos Aires/Argentina)

Solidificação dos laços de identidade nacional, preocupações higiênicas e moderação dos atos. A expectativa de reafirmar e disseminar essas três dimensões pelo ambiente urbano foi o que impulsionou a encenação dos espetáculos educacionais a partir de finais do século XIX.

\section{À guisa de conclusão: aproximações e distanciamentos}

Ao iluminar os espetáculos educacionais realizados no Rio de Janeiro e em Buenos Aires, perscrutando as possíveis "interseções, nas zonas em que [...] opõem-se e cruzam-se” (CANCLINI, 2005, p. 207), constata-se uma aproximação entre as preocupações educativas das duas 
cidades. A esse respeito, primeiramente, torna-se interessante acompanhar os percentuais de imigrantes presentes no Brasil e na cidade do Rio de Janeiro.

Quadro 3. Estrangeiros em relação à população total no Brasil

\begin{tabular}{c|c|c|c} 
Ano & $\mathbf{1 8 7 2}$ & $\mathbf{1 9 0 0}$ & $\mathbf{1 9 2 0}$ \\
\hline População Total & 10.112 .061 & 17.318 .556 & 30.635 .605 \\
\hline População de Estrangeiros & $388.459(3,84 \%)$ & $1.256 .806(7,25 \%)$ & $1.590 .378(5,19 \%)$
\end{tabular}

Fonte: Anuário Estatístico do Brazil. Rio de Janeiro: IBGE, v. 8, 1947/1948

* Esse número inclui os habitantes de nacionalidade ignorada

Quadro 4. Estrangeiros em relação à população total na cidade do Rio de Janeiro

\begin{tabular}{c|c|c|c} 
Ano & $\mathbf{1 8 9 0}$ & $\mathbf{1 9 0 6}$ & $\mathbf{1 9 2 0}$ \\
\hline População Total & 522.651 & 811.443 & 1.157 .873 \\
\hline População de Estrangeiros* $^{*}$ & $124.352(23,79 \%)$ & $210.515(25,94 \%)$ & $240.392(20,76 \%)$
\end{tabular}

Fonte: Anuário Estatístico do Brazil. Rio de Janeiro: IBGE, v. 2, 1936

* Este número inclui os habitantes de nacionalidade ignorada e os que adotaram a nacionalidade brasileira

O confronto desses percentuais relativos ao Brasil e ao Rio de Janeiro com aqueles referentes às características da Argentina e da capital portenha apresentados anteriormente (Quadros 1 e 2) reafirma a diferença do impacto do fenômeno imigratório. Em valores aproximados, entre os anos de 1869-1900, constata-se uma participação quatro vezes maior de imigrantes na composição populacional argentina em relação à brasileira; essa diferença, pela amostragem de 1914 e 1920, aumentou ainda mais: 30,3\% na Argentina frente aos 5,19\% no Brasil.

Para Boris Fausto e Fernando J. Devoto, quatro foram os principais fatores que impulsionaram os imigrantes europeus a trilhar, em quantidade bastante superior, o caminho para a Argentina e não para o Brasil: (1) "as informações que circulavam nos centros de emigração assinalavam as melhores condições salariais e mesmo de oportunidades no caso argentino" "11 (2) "a qualidade do clima, mais compatível com o europeu"; (3) "o temor das doenças contagiosas" incidia o preconceito, e o receio de que os trabalhadores imigrantes fossem tratados como escravos [...]"13 (2004, p. 174-75).

Uma vez sublinhada essa diferença relacionada ao número de imigrantes presentes nos dois países, para o exercício comparativo que foi construído por esta reflexão, é oportuno projetar o foco para as duas capi- 
tais. Ainda que as datas em que foram efetuados os levantamentos não sejam coincidentes, o que se nota no caso portenho é um aumento enfático do percentual de imigrantes no período de 1887 a 1895 (de 30\% para $52 \%$ ) e um decréscimo entre 1895 e 1914 (de 52\% para 49\%). No caso carioca, por seu turno, o que se percebe é um aumento no percentual de imigrantes entre os anos de 1890 e 1906 (23,79\% para 25,94\%), e uma redução entre 1906 e 1920 (de 25,94\% para 20,76\%). Finalmente, a comparação entre os índices estatísticos das duas sociedades aponta para o crescimento populacional que as cidades conheceram a partir da última década do século XIX. Em valores aproximados, no período de 1887 a 1914, o número de habitantes de Buenos Aires triplicou, enquanto a população carioca, no período de 1890 a 1920, duplicou.

O aumento significativo dos habitantes de Buenos Aires e do Rio de Janeiro concorreu para que as estratégias voltadas para a administração das populações integrassem as ações de governo acionadas nas duas capitais. Nesse movimento, embora o fenômeno da imigração carioca não tenha sido tão intenso quanto o portenho, as preocupações com a inculcação de comportamentos disciplinados e preceitos higiênicos e com a solidificação dos laços de identidade nacional na comunidade escolar e na população confluíram para que as encenações se constituíssem como uma constante na capital do Brasil.

Com efeito, ainda que não se refiram estritamente às encenações desses eventos, as prescrições do ensino primário ao longo dos anos 1920 frisavam a importância de os elementos da ordem do nacional serem trabalhados com as crianças:

[1] [...] estabelecer a correlação dos fatos entre si para determinar o espírito que lhes presidiu a formação e a evolução estabelecendo uma consciência precisa. [...]. O aluno terá o conhecimento exato do nosso valor como povo e não mais verá nos nossos feitos coisas esparsas, e sim conquistas sociais para a formação da nacionalidade (PROGRAMAS, 1926, p. 199).

[2] O que importa, no entanto, acima de tudo, é o cultivo do sentimento patriótico, que deve inculcar no ânimo do aluno duas idéias fundamentais: a de amor à terra pela sua grandeza, pela sua beleza e pelo que lhe devemos e a solidariedade que faz de um povo um todo único [...] (PROGRAMAS, 1929, p. 49). 
Pela leitura observa-se que as orientações concernentes ao desenvolvimento do patriotismo estavam explicitamente presentes na concepção educacional do período que sublinhava a relevância de as experimentaçôes serem incorporadas aos saberes e práticas do ensino primário. Estimular os alunos a conhecerem o meio à sua volta era também despertar o amor à sua região e, posteriormente, ao seu país (Cf. VIDAL, 1994, p. 25). Nesse sentido, não por acaso, muitas das encenações protagonizadas pelos escolares na cidade tiveram como mote datas e/ou símbolos que remetiam a acontecimentos "expressivos" da História do Brasil ("dia do Fico”, Independência, Proclamação da República, dia da Bandeira).

Nesse quadro de preocupações sobre os sentimentos pátrios, segundo Marta Carvalho, incluem-se aquelas relativas à "ameaça ao caráter nacional” corporificada na presença dos imigrantes (2000, p. 227). Isso porque, sob a perspectiva governamental de controle social, os estrangeiros, por partilharem um repertório diverso de tradições e hábitos, poderiam "contaminar" os demais habitantes com outras ideias, atitudes e comportamentos. Sobre esse aspecto específico, cabe relembrar as denominadas "Grandes Greves" de 1917 a 1920, que, em termos literais, tomaram de assalto a cidade do Rio de Janeiro. Dentre os participantes desses movimentos reivindicatórios, grande foi o número de trabalhadores estrangeiros, particularmente os que se dedicavam ao comércio e ao setor oficinal.

De posse dessas considerações, pontuar uma aproximação entre as iniciativas educativas das capitais no que tange à encenação dos espetáculos educacionais pelos ambientes urbanos, enfatizando que as preocupações cariocas consoantes ao nacionalismo conheceram significados semelhantes aos perseguidos em Buenos Aires, implica atentar para um elemento fundamental. Tanto lá quanto aqui essa modalidade de inculcar hábitos e comportamentos entre as crianças e os adultos foi largamente empregada como estratégia para a exaltação de valores e símbolos pátrios e para a difusão de hábitos moderados e preceitos higiênicos.

Entretanto, ao sublinhar essa aproximação entre as duas cidades não se deve desconsiderar uma variação que marcou as encenações dos espetáculos educacionais. Na capital portenha, a partir de finais do século XIX, "el Día del Árbol era la única fiesta que se celebraba sin que fuera una conmemoración cívica” (PUIGGRÓS, 1992, p. 53). As demais, de algum modo, guardavam vínculos com a História Argentina: celebração 
dos "heróis nacionais", comemoração de datas pátrias (particularmente os festejos de 25 de maio e 9 de julho), inauguração de praças e parques (quase sempre com a exaltação de algum acontecimento e/ou personagem significativo para o país), homenagens a personalidades que foram representativas para o desenvolvimento dos bairros onde se localizavam as escolas. Isso motivou, inclusive, a circulação de críticas como esta: "casi no pasa quincena sin que las escuelas en conjunto o parcialmente tengan que salir, concentrarse, desfilar... y volver a casa, cansados los niños, cansados los maestros, perdido un día y las horas dedicadas en preparativos, perdidos a los efectos de la enseñanza" ("Los desfiles escolares", La Obra: revista de educación, ciencias y letras, 5 de noviembre de 1922).

Já na capital carioca, as encenações desses eventos não se vinculavam diretamente à exaltação de símbolos nacionais e/ou "personagens representativos da História": saudação à visita do Rei e da Rainha da Bélgica na Quinta da Boa Vista, exibições de exercícios ginásticos encenados em campo de futebol, celebração dos "ideais de pacificação".

No tocante aos motivos que impulsionaram essa variação entre as duas cidades, os percentuais imigratórios elaborados por Boris Fausto e Fernando J. Devoto se constituem como indiciários, posto que no decênio 1921-1930 aportaram na Argentina 1,4 milhão de imigrantes (2004, p. 252). Desse modo, pode-se presumir que o fenômeno da imigração permanecia cooperando para o aumento da população. Nessa medida, os fatores que, a partir de finais do século XIX, confluíram para que o ensino primário assumisse ares de uma "educação patriótica", voltada para a "argentinização" da população, em certo sentido ainda constavam no rol das preocupações de governo. Isso justificaria a frequência e as escolhas das circunstâncias/datas para a encenação dos espetáculos educacionais.

Uma vez frisadas essas aproximações e a variação entre os espetáculos educacionais portenhos e cariocas, pode-se afirmar que os desfiles, evoluções e cânticos não encerravam a experiência educativa concretizada nos espaços citadinos. Afinal, os ensaios, preparação do "cenário", deslocamentos dos protagonistas e da audiência até os locais determinados despontavam como oportunidades para fazer com que os preceitos que estimulavam a realização dessas iniciativas repercutissem no cotidiano social. O investimento, no fundo, recaía sobre a tentativa de fazer com que essas atrações urbanas engendrassem modificações nos modos de ser, pensar e agir da comunidade escolar e dos demais habitantes. 


\section{REFERÊNCIAS}

ARAÚJO, Rosa Maria Barboza de. A Vocação do Pražer: a cidade e a família no Rio de Janeiro republicano. Rio de Janeiro: Rocco, 1993.

BRETAS, Marcos Luiz. A Guerra das Ruas: povo e polícia na cidade do Rio de Janeiro. Rio de Janeiro: Arquivo Nacional, 1997.

CANCLINI, Nestor García Diferentes, Desiguais e Desconectados: mapas da interculturalidade. Rio de Janeiro: Editora da UFRJ, 2005.

CARNEIRO LEÃO, Antônio. O Ensino na Capital do Brasil. Rio de Janeiro: Typ. do Jornal do Commércio, 1926.

CARVALHO, Marta Maria Chagas de. "Reformas da Instrução Pública”. In: LOPES, Eliane M. T.; FARIA FILHO, Luciano M.; VEIGA, Cynthia G. 500 anos de Educação no Brasil. Belo Horizonte: Autêntica, 2000, p. 225-51.

CHALHOUB, Sidney. "Zadig e a História". In: Visões da Liberdade: uma história das últimas décadas da escravidão na corte. São Paulo: Companhia das Letras, 1990, p. 13-28.

CHALHOUB, Sidney. Trabalho, Lar e Botequim: o cotidiano dos trabalhadores no Rio de Janeiro da Belle Époque. São Paulo: Brasiliense, 1986.

CHALHOUB, Sidney. Cidade Febril: cortiços e epidemias na corte imperial. São Paulo: Companhia das Letras, 1996.

COGGIOLA, Osvaldo. "Buenos Aires, Cidade, Política, Cultura”. In: Revista Brasileira de História. São Paulo: ANPUH; v. 17, n. 34, p. 101-118, 1997.

FAUSTO, Boris; DEVOTO, Fernando J. Brasil e Argentina: um ensaio de história comparada (1850-2002). São Paulo: Editora 34, 2004.

FOUCAULT, Michel. Segurança, Território, População: curso dado no Collège de France (1977-1978). São Paulo: Martins Fontes, 2008.

GONDRA, José Gondra. Artes de Civilizar medicina, higiene e educação escolar na Corte Imperial. Rio de Janeiro: EdUERJ, 2004.

GORELIK, Adrián. La Grilla y el Parque. Espacio público y cultura urbana en Buenos Aires, 1887-1936. Buenos Aires: Universidad Nacional de Quilmes, 2004.

GRAHAM, Sandra Lauderdale. Proteção e Obediência: criadas e seus patrões no Rio de Janeiro 1860-1910. São Paulo: Companhia das Letras, 1992.

GVIRTZ, Silvina (Org.). Escuela Nueva en Argentina y Brasil: visiones comparadas. Buenos Aires: Niño y Dávila Editores, 1996.

GVIRTZ, Silvina; AUGUSTOWSKY, Gabriela. Imágenes de nuestra escuela. Argentina, 1900-1960. Buenos Aires: Santillana, 2002.

HERSCHMANN, Micael M.; PEREIRA, Carlos Alberto Messeder (Orgs.). A invenção do Brasil moderno: medicina, educação e engenharia nos anos 20-30. Rio de Janeiro: Rocco, 1994.

HOBSBAWM, Eric; RANGER, Terence (Orgs.). A Invenção das Tradições. Rio de Janeiro: Paz e Terra, 1984.

LIERNUR, Jorge. F.; SILVESTRI, Graciela. El Umbral de la Metrópolis: transformaciones técnicas y cultura en la modernización de Buenos Aires (1870-1930). Buenos Aires: Editorial Sudamericana, 1993.

LIONETTI, Lucía. La Misión Política de La Escuela Pública. Formar a los ciudadanos de la república (1870-1916). Buenos Aires: Miño y Dávila, 2007.

LIONETTI, Lucía. "La función republicana de la escuela pública. La formación del ciu- 
dadano en argentina a fines del siglo XIX". In: Revista Mexicana de Investigación Educativa; año/v. 10. México: oct.-diciem. p. 1225-1255, 2005.

"Los desfiles escolares". La Obra: revista de educación, ciencias y letras. Buenos Aires, 05 de noviembre de 1922.

MONARCHA, Carlos. A reinvenção da cidade e da multidão: dimensões da modernidade brasileira - a escola nova. São Paulo: Cortes; Autores Associados, 1989.

NUNES, Clarice. “(Des)encantos da Modernidade Pedagógica”. In: LOPES, Eliane M. T.; FARIA FILHO, Luciano M.; VEIGA, Cynthia G. 500 anos de Educação no Brasil. Belo Horizonte: Autêntica, 2000, p. 371-98.

NUNES, Clarice. "A Escola reinventa a Cidade". In: HERSCHMANN, Micael M.; PEREIRA, Carlos A. M. (Orgs.). A invenção do Brasil moderno: medicina, educação e engenharia nos anos 20-30. Rio de Janeiro: Rocco, 1994, p. 180-201.

OLARÓN, Cecilia. "Imágenes de unos rituales escolares". En: GVIRTZ, Silvina (Org.). Textos para Repensar el Día a Día Escolar. Sobre cuerpos, vestuarios, espacios, lenguajes, ritos y modos de convivencia en nuestra escuela. Buenos Aires: Santillana, 2005, p. 79102.

OLIVEIRA, Beatriz Santos de. A modernidade oficial: a arquitetura das escolas públicas do Distrito Federal (1928-1940). Dissertação (Mestrado), FAU-USP, São Paulo, 1991.

PALAMIDESSI, Mariano I. "Curriculum y problematizaciones: moldes sobre lo cotidiano. In: GVIRTZ, Silvina (Org.). Textos para Repensar el Dia a Dia Escolar. Sobre cuerpos, vestuarios, espacios, lenguajes, ritos y modos de convivencia en nuestra escuela. Buenos Aires: Santillana, 2005, p. 213-42.

"Programas para o Ensino Primário Carioca". In: Boletim da Prefeitura do Districto Federal (RJ) - publicado pela Secretaria do Gabinete do Prefeito. Rio de Janeiro: Officinas Graphicas do Jornal do Brasil; jan. - dez. 1926.

Programas para os Jardins de Infância e para as Escolas Primárias. Prefeitura do Districto Federal. Rio de Janeiro: Off. Graphicas do Jornal do Brasil, 1929.

PUIGGRÓS, Adriana. "La educación argentina desde la reforma Saavedra-Lamas hasta el fin de la década infame. Hipótesis para la discusión". En: (Dir.). Historia de la Educación en la Argentina III. Buenos Aires: Galerna, 1992, p. 15-97.

SEVCENKO, Nicolau. "O Prelúdio Republicano, Astúcias da Ordem e Ilusões do Progresso". In: . (Org.). História da Vida Privada no Brasil III. República: da Belle Époque à Era do Rádio. São Paulo: Companhia Das Letras, 1998.

SILVA, José Cláudio Sooma. Teatros da Modernidade: representações de cidade e escola primária no Rio de Janeiro e em Buenos Aires nos anos 1920. Tese (Doutorado), UERJ, Rio de Janeiro, 2009.

SOARES, Gabriela Pellegrino. Semear Horizontes: uma história da formação de leitores na Argentina e no Brasil, 1915-1954. Belo Horizonte: Editora da UFMG, 2007.

VAGO, Tarcísio Mauro. Cultura Escolar, Cultivo de Corpos: educação physica e Gymnastica como práticas constitutivas dos corpos de crianças no ensino público primário de Belo Horizonte (1906-1920). Bragança Paulista: EDUSF, 2002.

VIDAL, Diana Gonçalves. "Cinema, laboratórios, ciência físicas e Escola nova”. In: Cadernos de Pesquisa, n. 89, p. 24-8, maio 1994. 


\section{NOTAS}

1 Referência à administração de Francisco Pereira Passos (1902-1906), que marcadamente contribuiu para se pensar os espaços e tempos sociais cariocas a partir do olhar técnico da engenharia e da medicina higienista. Tal modelo administrativo foi estendido, via de regra, pelos prefeitos que o sucederam.

2 No período de Carneiro Leão (1922-1926), a extensão do curso primário era de sete anos, havendo as escolas de dois turnos com jornada diária de 4 horas e 20 minutos (manhã: das $7 \mathrm{~h} 50$ às $12 \mathrm{~h} 10$; e tarde: das $12 \mathrm{~h} 20$ às 16h40) e as de turno único com jornada diária de 5 horas (das 11h às 16h). Na gestão de Fernando de Azevedo (1927-1930), a extensão do curso primário era de cinco anos (sendo o último referente a um curso pré-vocacional técnico elementar) e as escolas tinham dois turnos com jornada diária de 4 horas e 30 minutos (manhã: das 7 h30 às $12 \mathrm{~h}$; e tarde: das $12 \mathrm{~h} 30$ às $17 \mathrm{~h}$ ) ou turno único, também com jornada diária de 4 horas e 30 minutos (das $11 \mathrm{~h}$ às 15h30).

3 O Diretor de Instrução, Antônio Carneiro Leão, em 1926, cogitou a possibilidade da realização de 400 espetáculos educacionais por ano (1926, p. 147).

4 Arquivo Geral da Cidade do Rio de Janeiro; códice: 34-4-3; Diretor Geral da Instrução Pública: Ernesto Nascimento Silva.

5 Arquivo Geral da Cidade do Rio de Janeiro; códice: 35-1-3; Diretor Geral da Instrução Pública: Antônio Carneiro Leão.

6 Essas solicitações, dentre outras circulares enviadas pela Diretoria de Instrução Pública ao longo da década de 1920, encontram-se reunidas na pasta "Copiador de Ofícios, 3 a Seção da Diretoria Geral de Instrução Pública".

7 Em 1927, no campo do Fluminense Futebol Clube, foram celebrados os "ideais de pacificação", neste espetáculo estiveram presentes 3 mil alunos.

8 A esse respeito, dialogo também com os trabalhos de Gabriela P. Soares (2007, p. 32), Mariano I. Palamidessi (2005, p. 219) e Silvina Gvirtz (1996, p. 75).

9 Para Osvaldo Coggiola, em termos da atração exercida sobre os imigrantes europeus, a Argentina teria superado inclusive os Estados Unidos (1997, p. 101).

10 Amostragem idêntica foi apresentada por Cecília Olarón (2005, p. 85).

11 Sobre esse aspecto específico, cumpre recordar que, em finais do século XIX e no começo do XX, a Argentina vivia um período de grande expansão econômica, tornando-se a maior produtora mundial de carne e de grãos, ao passo que a produção cafeeira no Brasil atravessava uma de suas crises mais graves (Cf. FAUSTO; DEVOTO, 2004).

12 A esse respeito, pode-se citar o caso do Rio de Janeiro, onde a febre amarela, cholera morbus, peste, varíola, difteria, tifo, febre tifóide, tuberculose aberta e lepra ulcerada eram algumas das doenças que infestavam a cidade. Para que se tenha uma ideia do "perigo" de contaminação, entre 1850 e 1901, 56 mil cariocas morreram em consequência da febre amarela (Cf. CHALHOUB, 1986; 1996; GRAHAM, 1992).

13 Nesse particular, é presumível que a escravidão ter sido abolida com uma antecedência de 35 anos nas províncias do interior da Argentina (1853) e de 28 anos em Buenos Aires (1860), em relação ao Brasil (1888), contribuía para essa situação (Cf. FAUSTO; DEVOTO, 2004). 
Recebimento: 10/03/2010

Aprovação: 16/08/2010

\section{Contato:}

Universidade Federal do Rio de Janeiro

Faculdade de Educação.

Avenida Pasteur, 250

Praia Vermelha

Rio de Janeiro - RJ CEP 20550-900 